\title{
Morphological and physiological plasticity response to low nitrogen stress in black cottonwood (Populus deltoides Marsh.)
}

\author{
Cun Chen ${ }^{1,2}$ - Yanguang $\mathrm{Chu}^{1,2} \cdot$ Qinjun Huang ${ }^{1,2}$. \\ Changjun Ding ${ }^{1,2} \cdot$ Weixi Zhang ${ }^{1,2} \cdot$ Bo Li $^{1,2}$. \\ Jing Zhang ${ }^{1,2} \cdot$ Xiaohua Su ${ }^{1,2,3}$
}

Received: 12 April 2020 / Accepted: 19 July 2020 / Published online: 4 June 2021

(C) The Author(s) 2021

\begin{abstract}
It is important to evaluate nitrogen use efficiency and nitrogen tolerance of trees in order to improve their productivity. In this study, both were evaluated for 338 Populus deltoides genotypes from six provenances. The plants were cultured under normal nitrogen $(750 \mu \mathrm{M}$ $\left.\mathrm{NH}_{4} \mathrm{NO}_{3}\right)$ and low nitrogen $\left(5 \mu \mathrm{M} \mathrm{NH} \mathrm{NO}_{3}\right)$ conditions for 3 months. Growth, chlorophyll content and glutamine synthetase activity of each genotype were measured. Under low nitrogen, heights, ground diameter, leaf area, leaf and root biomass, and chlorophyll contents were significantly lower than those under normal nitrogen level. Correlation analysis showed that nutrient distribution changed under different nitrogen treatments. There was a negative correlation
\end{abstract}

Project funding: This study was funded by the National Natural Science Foundation of China (Grant No. 31670677), and the Basic Research Fund of RIF (Grant No. CAFYBB2020SZ002).

The online version is available at http://www.springerlink.com.

Corresponding editor: Yanbo Hu.

Supplementary Information The online version contains supplementary material available at https://doi.org/10.1007/ s11676-021-01338-4.

Xiaohua Su

suxh@caf.ac.cn

1 State Key Laboratory of Tree Genetics and Breeding, Research Institute of Forestry, Chinese Academy of Forestry, Beijing 100091, People's Republic of China

2 Key Laboratory of Tree Breeding and Cultivation, State Forestry and Grassland Administration, Beijing 100091, People's Republic of China

3 Co-Innovation Center for Sustainable Forestry in Southern China, Nanjing Forestry University, Nanjing 210037, People's Republic of China between leaf traits and root biomass under normal nitrogen level, however, the correlation became positive in low nitrogen treatment. Moreover, with the decrease of nitrogen level, the negative correlation between leaf morphology and chlorophyll levels became weakened. The growth of the genotypes under the two treatments was evaluated by combining principal component analysis with a fuzzy mathematical membership function; the results showed that leaf traits accounted for a large proportion of the variation in the evaluation model. According to the results of comprehensive evaluation of plants under the two treatments, the $338 P$. deltoides genotypes could be divided into nine categories, with wide genotypic diversity in nitrogen use efficiency and low nitrogen tolerance. As a result, $26 \mathrm{~N}$-efficient genotypes and $24 \mathrm{~N}$-inefficient genotypes were selected. By comparative analysis of their morphological and physiological traits under the two treatments, leaf traits could be significant indicators for nitrogen use efficiency and nitrogen tolerance, which is of considerable significance for breeding poplar varieties with high nitrogen use efficiencies.

Keywords Populus deltoides · Nitrogen deficiency · Nitrogen use efficiency · Comprehensive evaluation . Genotypic diversity

\section{Introduction}

Nitrogen $(\mathrm{N})$ is an essential mineral element and an important component of many biological macromolecules such as nucleic acids, proteins, hormones and chlorophyll. Nitrogen plays a crucial role in the growth and development of plants (Binkley and Högberg 2016; Rubio-Asensio and Bloom 2017; Cánovas et al. 2018). Both inorganic and organic $\mathrm{N}$ are absorbed by roots and transported to every 
part of the plant. Under the action of various enzymes, $\mathrm{N}$ is transformed into several organic substances that participate in essential metabolic processes (Rennenberg et al. 2010; Tegeder and Masclaux-Daubresse 2018). Plant productivity is closely related to $\mathrm{N}$ levels in the soil (Mamashita et al. 2015). To increase crop yields, exgenous $\mathrm{N}$ application is a common method to increase the $\mathrm{N}$ content in the soil. However, $\mathrm{N}$ application increases crop production costs and may cause environmental pollution (Robertson and Vitousek 2009; Sutton et al. 2011). Tree species have high demands for $\mathrm{N}$ but some grow in poor quality soil where the $\mathrm{N}$ availability is low (Rennenberg et al. 2010; Balasus et al. 2012), leading to low forest quality. Undoubtedly, the application of $\mathrm{N}$ fertilizer to promote plant growth in such situations will increase costs. Poplar species are widely planted because they are fast-growing, reproduce easily and display strong adaptability to a variety of environments, and thus have important economic and ecological protection values (Jansson and Douglas 2007; Polle et al. 2013). However, the growth of poplar species is constrained by nitrogen availability. Therefore, it is important to understand mechanisms underlying poplar adaptation to $\mathrm{N}$ limitation in order to enhance $\mathrm{N}$ tolerance and cultivate varieties with high nitrogen use efficiency (NUE) (Ren et al. 2015; Meng et al. 2018).

The response mechanisms of trees to $\mathrm{N}$ starvation or limitation have been studied in terms of phenotypic and physiological characteristics (Rennenberg et al. 2010). Nitrogen starvation affects the allocation of $\mathrm{N}$ within the plant and will stimulate the transport of more nutrients to underground parts to encourage the growth of roots, especially fine roots, to absorb more $\mathrm{N}$ from the soil (Gao et al. 2015; Kiba and Krapp 2016; Luo et al. 2019; Qin et al. 2019). Root structure displays high plasticity in different environments with different N levels (Dathe et al. 2016; Dong et al. 2016; Luo and Luo 2017). Similar to the roots, leaf characteristics, especially leaf area which is closely related to biomass, are sensitive to changes in $\mathrm{N}$ availability (Tavarini et al. 2016; Zeng et al. 2017; Mao et al. 2018). Therefore, leaf characteristics are often used as indexes to evaluate site conditions and plant growth (Pérezharguindeguy et al. 2013). The composition of soil fauna and microbial communities can be affected by $\mathrm{N}$ levels, which plays an important role in the growth of plants, especially roots (Hodge et al. 2000; Ouyang et al. 2017; Sun et al. 2017; Bian et al. 2019).

The response of poplar species to low $\mathrm{N}$ levels has mainly been studied using a single genotype or two contrasting genotypes. Few studies have been conducted on the adaptability and NUE of natural populations of Populus (Kalcsits and Guy 2016). It is well known that selecting poplar genotypes suitable for the site conditions will achieve high productivity (Ghezehei et al. 2016, 2019). Populus species have been planted over large areas of the world on various site conditions, so it is particularly important to select clones scientifically (Truax et al. 2014; Ghezehei et al. 2019).

Populus deltoides Marsh. is a highly suitable short rotation timber species in the middle latitudes of the world. $P$. deltoides is often used in hybrid breeding which has important research value (Fahrenkrog et al. 2017). P. deltoides germplasm resources have high genetic diversity (Fahrenkrog et al. 2017; Chen et al. 2020). However, the NUE and response to low $\mathrm{N}$ stress of a large number of genotypes in the P. deltoides population are unknown. Therefore, in this study, the phenotypic and physiological indexes of 338 genotypes of $P$. deltoides were observed under normal N supply and low $\mathrm{N}$ stress, and the growth of each genotype was evaluated. It was hypothesized that the growth of each genotype (roots, stems and leaves) would be inhibited under low $\mathrm{N}$ stress and that the response of different genotypes to the change in $\mathrm{N}$ levels would be different. This study aimed to evaluate the NUE and low N tolerance of different genotypes. The results could provide a theoretical basis for clonal selection in poplar breeding and lay the foundation for further research on molecular mechanism regulation under low $\mathrm{N}$ stress.

\section{Materials and methods}

\section{Plant materials}

Through international cooperation and exchange of germplasm resources, $P$. deltoides germplasm was collected from main distribution areas in North America. A germplasm bank was established in Ningyang County, Tai' an City,

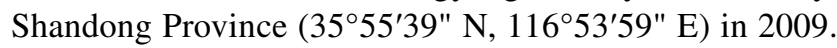
Cuttings of 338 genotypes of $P$. deltoides were selected from this bank (Fig. 1). These individuals came from six provenances of three different basins. Among them, 18 genotypes were from Iowa ('Iow'), 10 were from two sampling sites in Missouri ('Mis'), and 117 and 92 individuals were from eight sampling sites in Louisiana ('Lou') and five in Tennessee ('Ten'), respectively. These provenances were located in the Mississippi River basin. In the Columbia River basin, 16 genotypes were from Washington ('Was'). In the Saint Lawrence River basin, 85 individuals were from seven sampling sites in Quebec, Canada ('Que'). These materials were similar to those used in a previous study (Chen et al. 2020).

\section{Plant cultivation and experimental design}

One-year-old stem cuttings ( $15 \mathrm{~cm}$ in length, $1.0-1.5 \mathrm{~cm}$ in diameter) of the 338 genotypes were rooted and cultured in nutritional pots $(5 \mathrm{~cm}$ height, $5 \mathrm{~cm}$ diameter) filled with medium (nutrient soil: perlite $=9: 1$ ). For every genotype, there were 20 cuttings. The plants were cultivated 

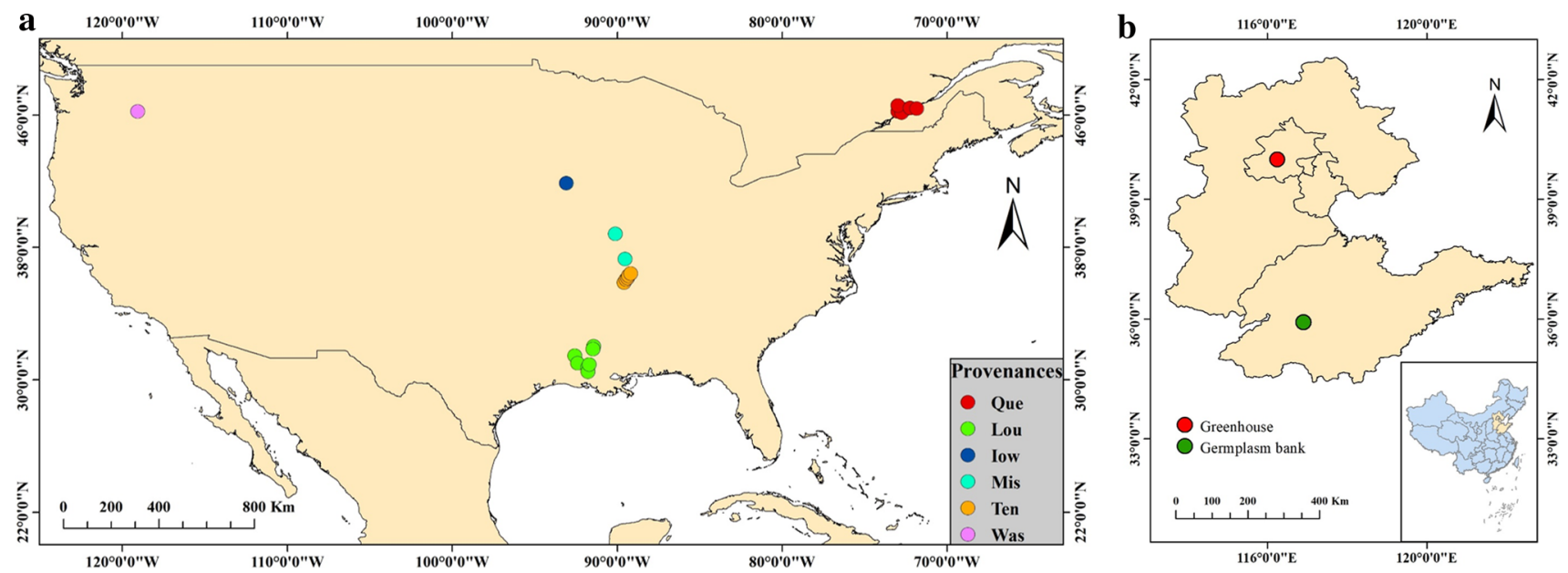

Fig. 1 Locations of a the provenances and $\mathbf{b}$ the germplasm bank of Populus deltoides. Que, Quebec; Lou, Louisiana; Iow, Iowa; Mis, Missouri; Ten, Tennessee; Was, Washington

for 30 days, the root systems carefully washed, replanted in new pots $(20 \mathrm{~cm}$ height, $10 \mathrm{~cm}$ diameter) with vermiculite to hold air, water and nutrients. The plants were cultured with water for 15 days, and then irrigated every other day with $100 \mathrm{~mL}$ of one-tenth strength Hoagland nutrient solution containing $0.4 \mathrm{mM} \mathrm{Ca}\left(\mathrm{NO}_{3}\right)_{2} \cdot 4 \mathrm{H}_{2} \mathrm{O}, 0.5 \mathrm{mM}$ $\mathrm{KNO}_{3}, 0.1 \mathrm{mM} \mathrm{NH} \mathrm{NO}_{3}, 0.1 \mathrm{mM} \mathrm{KH} \mathrm{PO}_{4}, 0.4 \mathrm{mM}$ $\mathrm{MgSO}_{4} \cdot 7 \mathrm{H}_{2} \mathrm{O}, 5 \mu \mathrm{M}$ Fe-EDTA [pH $\left.=5.5\right], 2.5 \mathrm{nM} \mathrm{KI}$, $50 \mathrm{nM} \mathrm{H}_{3} \mathrm{BO}_{3}, 50 \mathrm{nM} \mathrm{MnSO} \cdot 4 \cdot 4 \mathrm{H}_{2} \mathrm{O}, 15 \mathrm{nM} \mathrm{ZnSO}{ }_{4} \cdot 7 \mathrm{H}_{2} \mathrm{O}$, $0.5 \mathrm{nM} \mathrm{Na}_{2} \mathrm{MoO}_{4} \cdot 2 \mathrm{H}_{2} \mathrm{O}, 0.05 \mathrm{nM} \mathrm{CuSO}_{4} \cdot 5 \mathrm{H}_{2} \mathrm{O}$ and $0.05 \mathrm{nM}$ $\mathrm{CoCl}_{2}$. The solution was adjusted to $\mathrm{pH}$ 6.0. After 20 days, 12 plants of each genotype with similar growth performance were selected and randomly divided into two groups of six plants, one group as the control (CK) and the other the $\mathrm{N}$ stress group (low N; LN). Plants of the LN and CK were cultivated with modified Hoagland nutrient solution $(0.4 \mathrm{mM}$ $\mathrm{CaCl}_{2} \cdot 2 \mathrm{H}_{2} \mathrm{O}, 0.5 \mathrm{mM} \mathrm{KCl}, 0.1 \mathrm{mM} \mathrm{KH_{2 }} \mathrm{PO}_{4}, 0.4 \mathrm{mM}$ $\mathrm{MgSO}_{4} \cdot 7 \mathrm{H}_{2} \mathrm{O}, 5 \mu \mathrm{M}$ Fe-EDTA $[\mathrm{pH}=5.5], 2.5 \mathrm{nM} \mathrm{KI}$, $50 \mathrm{nM} \mathrm{H}_{3} \mathrm{BO}_{3}, 50 \mathrm{nM} \mathrm{MnSO} \cdot 4 \cdot 4 \mathrm{H}_{2} \mathrm{O}, 15 \mathrm{nM} \mathrm{ZnSO} \cdot 7 \mathrm{H}_{2} \mathrm{O}$, $0.5 \mathrm{nM} \mathrm{Na}_{2} \mathrm{MoO}_{4} \cdot 2 \mathrm{H}_{2} \mathrm{O}, 0.05 \mathrm{nM} \mathrm{CuSO}_{4} \cdot 5 \mathrm{H}_{2} \mathrm{O}$ and $0.05 \mathrm{nM}$ $\mathrm{CoCl}_{2}$ ) containing $5 \mu \mathrm{M}$ or $750 \mu \mathrm{M} \mathrm{NH}_{4} \mathrm{NO}_{3}$, respectively, every two days. The treatments were carried out for 3 months until distinct morphological differences were observed and then harvested. All treatments were carried out in the greenhouse of the Chinese Academy of Forestry $\left(40^{\circ} 0^{\prime} 10^{\prime \prime} \mathrm{N}\right.$, $\left.116^{\circ} 14^{\prime} 38^{\prime \prime} \mathrm{E}\right)$.

\section{Measurements of chlorophyll and glutamine synthetase (GS) activity}

After 2 months of treatments, three plants with similar heights $(\mathrm{H})$ were selected for each genotype in each treatment. Three mature functional leaves of each plant were collected, placed into liquid $\mathrm{N}$, and stored at $-80{ }^{\circ} \mathrm{C}$ for the determination of chlorophyll contents and GS activity. Concentrations of chlorophyll (Chl a, $\mathrm{Chl} \mathrm{b}$ and total $\mathrm{Chl}$ ) were analyzed using the $96 \%$ ethanol method (Lichtenthaler and Wellburn 1983). The activity of GS was determined using the relevant biochemical kit (GS-1-Y, Cominbio, Suzhou, China).

\section{Determination of leaf morphological characteristics and plant biomass}

The initial height (H0) and the ground diameter (GD0) of each plant were determined before the treatments. After treatments, three plants with similar growth performances were selected for each genotype in each treatment for harvesting, and final heights $(\mathrm{Hn})$ and the ground diameters (GDn) were measured. Before harvesting, five mature leaves that had formed during the treatments were collected from each plant to determine leaf morphological characteristics. Fresh weight of the leaves was recorded, and leaf length, width and area were measured using a leaf area meter (Yaxin-1241, Beijing Yaxin Liyi Technology Co., Ltd., Beijing, China). Root systems of each plant were washed and fresh weight was determined. Leaves and roots were then dried at $75^{\circ} \mathrm{C}$ for $96 \mathrm{~h}$ until constant weight and dry weights of the leaves and roots were recorded.

\section{Verification experiment}

Based on the results of the comprehensive evaluation, three genotypes were randomly selected from plants of different $\mathrm{N}$ utilization types to verify the evaluation results. The culture method used for the plants was similar to that described previously; however, it differed in that plants of each genotype with similar heights were randomly divided 
into three groups, with six plants in each group. Plants in each of the three groups were cultivated with the application of modified Hoagland nutrient solution containing $5 \mu \mathrm{M}$ (LN), $750 \mu \mathrm{M}$ (CK) or $3000 \mu \mathrm{M}$ (high nitrogen; HN) $\mathrm{NH}_{4} \mathrm{NO}_{3}$, every 2 days.

The measured trait parameters included the height and ground diameter of each plant, the morphological parameters and chlorophyll content of the leaves, and the biomass values of the roots, stems, petioles, and leaves without petioles after the $\mathrm{N}$ treatments. In addition, the net photosynthetic rate $(\mathrm{Pn})$ and transpiration rate $(\mathrm{Tr})$ of mature leaves were measured from 09:00 to 11:00 using a portable photosynthesis system (Li-Cor-6400, LI-COR Inc., Lincoln, NE, USA) with an attached light-emitting diode (LED) light source. The light intensity was $1000 \mu \mathrm{mol} \mathrm{m} \mathrm{m}^{-2} \mathrm{~s}^{-1}$, the $\mathrm{CO}_{2}$ concentration $400 \mu \mathrm{mol} \mathrm{mol}^{-1}$ and the gas flow rate $500 \mu \mathrm{mol} \mathrm{s}^{-1}$.

\section{Statistical analyses}

All data were recorded using Excel software, and the mean value of every parameter of each genotype was calculated. Correlation analysis between parameters was carried out using the package 'corrplot' in R. Heat maps, violin plots and network diagrams of each parameter were drawn using OmicShare tools (www.omicshare.com/tools). A Tukey test was used for comparing the means of the parameters. For principal component analysis (PCA), the data were standardized and computed using SPSS 17.0 for Windows (SPSS, Chicago, IL, USA). In order to explain the extracted principal components clearly, the factors were rotated using the maximum variance method with Kaiser normalization. Afterwards, based on the result of the PCA, comprehensive analysis of each genotype were conducted using the fuzzy mathematics membership function method. The comprehensive evaluation value was calculated using three equations as follows:

$y\left(P C_{i j}\right)=\left(P C_{i j}-P C_{j \min }\right) /\left(P C_{j \max }-P C_{j \min }\right)$,

where $y\left(P C_{i j}\right)$ is the fuzzy mathematical membership function value of the $j$-th principal component of the $i$-th poplar genotypes, $P C_{i j}$ is the score of the $j$-th principal component of the $i$-th poplar genotypes, $P C_{j \min }$ is the minimum value of the $j$-th principal component score of all genotypes and $P C_{\text {jmax }}$ is the maximum value.

$w_{j}=r_{j} / \sum_{j}^{n} r_{j}$,

where $w_{j}$ and $r_{j}$ are the weight and the contribution rate of the $j$-th principal component, respectively.
$P_{C E-i}=\sum_{j}^{n} w_{j} \times y\left(P C_{i j}\right)$

where $P_{C E-i}$ is the comprehensive evaluation value of the $i$-th poplar genotypes.

\section{Results}

\section{Morphological and physiological traits of the genotypes}

P. deltoides genotypes were sensitive to the change of available $\mathrm{N}$ in the culture environment. Compared with plants cultured under normal $\mathrm{N}$ supply (CK), growth of plants under low $\mathrm{N}(\mathrm{LN})$ was inhibited. Before the $\mathrm{N}$ treatment, there was no significant difference in height between LN and CK treatments (Fig. 2), and the means were 34.68 and $34.62 \mathrm{~cm}$, respectively (Table S1). Average ground diamters of plants in the LN treatment was $3.41 \mathrm{~mm}$, significantly higher than that of the CK plants ( $3.34 \mathrm{~mm} ; p<0.05$; Fig. 2 and Table S1). After the treatments, heights and ground diameters of plants in the $\mathrm{LN}$ treatment were significantly lower than those in the CK treatment $(p<0.01 ;$ Fig. 2$)$. The mean fresh weight (RFW) and mean dry weight (RDW) of roots of LN treated plants were 1.70 and $1.01 \mathrm{~g}$, respectively. These values were significantly lower than those of the plants in the CK group $(p<0.01$; Fig. 2 and Table S1). Growth of leaves was obviously inhibited in the LN treatment, and this manifested as decreases in length (LL), width (LW), area (LA), fresh weight (LFW) and dry weight (LDW) ( $p<0.01$; Fig. 2). Under LN treatment, chlorophyll contents also decreased significantly ( $p<0.01$; Fig. 2$)$. However, the change in $\mathrm{N}$ concentration had no significant effect on GS activity (Fig. 2).

\section{Correlation analysis of morphological and physiological parameters}

Under both treatments (CK and LN), there was a significant positive correlation between leaf morphological parameters $(p<0.01$; Fig. 3a and b). A similar correlation also existed between the physiological parameters $(p<0.01$; Fig. 3a and b). In addition, there was a significant positive correlation between stem growth and growth of leaves and roots $(p<0.01$; Fig. 3a and b). There was also a negative correlation between leaf physiological and morphological parameters (Fig. $3 a$ and $b$ ).

There were differences in the correlation relationships of all parameters under the two treatments (Fig. $3 \mathrm{c}$ and d), specifically, there were significant positive correlations between RFW and leaf morphological parameters in the LN treatment ( $p<0.01$; Fig. 3a and b). In the controls, there were 

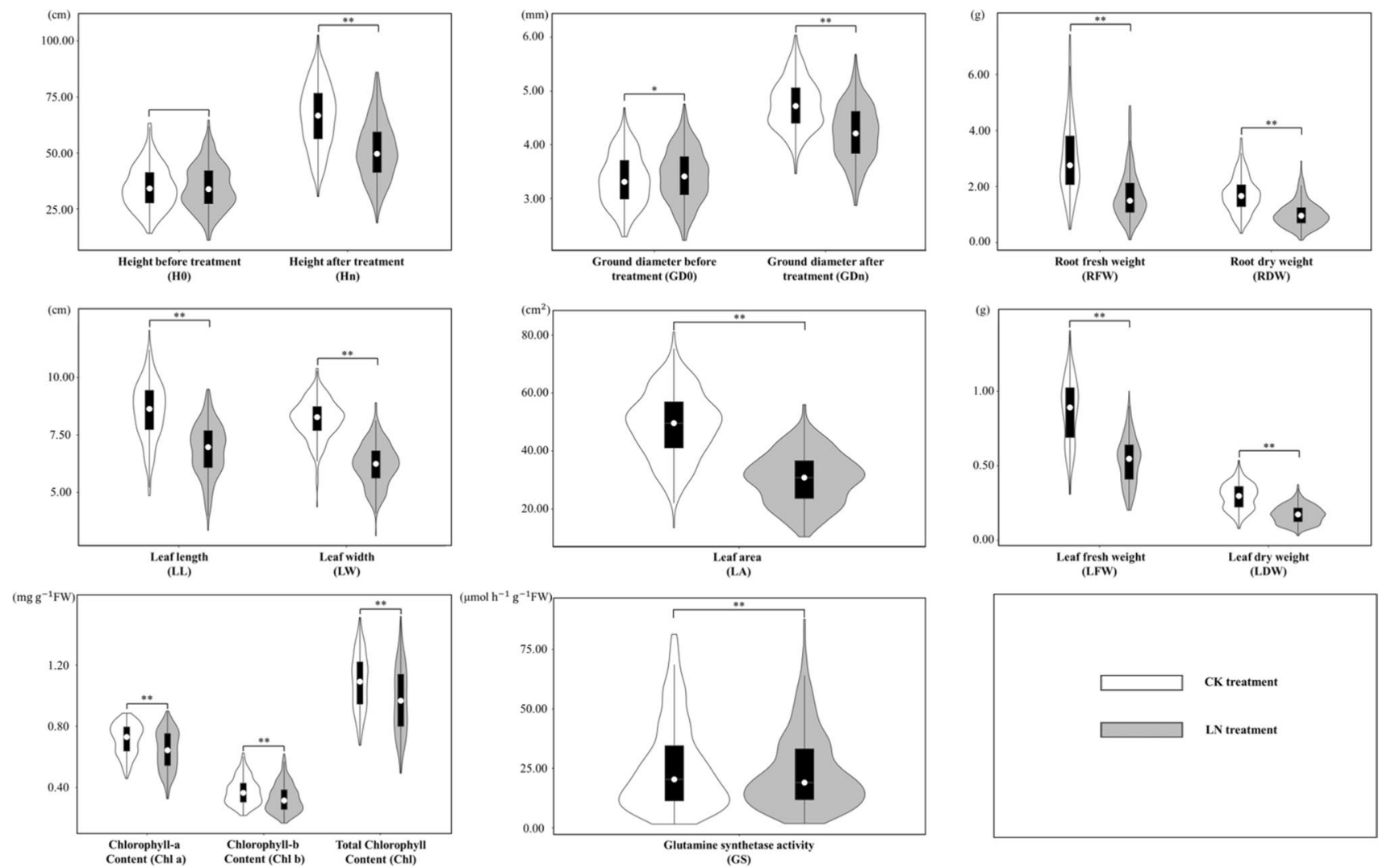

Fig. 2 Height $(\mathrm{H})$, ground diameter (GD), root biomass, leaf morphology and biomass, chlorophyll content and glutamine synthetase (GS) activity of Populus deltoides under normal N supply (CK; white) and low $\mathrm{N}$ supply (LN; gray) *: $p<0.05, * *: p<0.01$

significant negative correlations between leaf morphological parameters and chlorophyll contents $(p<0.01$; Fig. $3 \mathrm{a}$ and b), but this negative correlations were weak in $\mathrm{LN}$ treatment. The same results can be found by comparing the network diagrams of the CK (Fig. 3c) and LN (Fig. 3d) treatments.

\section{Principal Component Analysis (PCA) of morphological and physiological parameters}

Correlation analysis results show that there was a strong correlation between the measured trait parameters, whether under $\mathrm{CK}$ treatment or $\mathrm{LN}$ treatment. After removing the parameter $\mathrm{Chl}(\mathrm{Chl} \mathrm{a}+\mathrm{Chl} b)$, PCA was performed for 12 parameters after $\mathrm{N}$ treatment. The Kaiser-Meyer-Olkin (KMO) test and Bartlett's test of sphericity were carried out on the parameters under the two treatments, and the results show that they were suitable for principal component analysis $(\mathrm{KMO}>0.7, p<0.001)$.

For both treatments, four principal components with eigenvalues $>1$ after rotation were extracted (Wang et al. 2018a, b), and the cumulative variance contribution rates reached $85.7 \%$ and $87.1 \%$, respectively (Table 1 ). In addition, according to the rotation component matrices, the composition and biological interpretation of the four principal components were similar in both treatments (Table 2). The first principal component (PC1) was leaf character factor, upon which the LFW, LDW, LA, LL and LW had a large loading. The second principal component (PC2) was physiological index factor (Chl a, Chl $\mathrm{b}$ and GS). The mean root fresh weight (RFW) and mean root dry weight (RDW) were the main load factors of the third principal component (PC3), which was named root character factor. The fourth principal component (PC4), stem character factor, mainly contained the variation information of the final heights (Hn) and final ground diameters (GDn). The four extracted principal components reflect adequately the growth of each $P$. deltoides genotype under CK and LN treatments.

\section{Comprehensive evaluation of plants}

Different genotypes varied in response to different $\mathrm{N}$ treatments. Therefore, the results of the PCA and fuzzy mathematics membership function method were used to evaluate individuals under $\mathrm{CK}$ and $\mathrm{LN}$ treatment. 
a

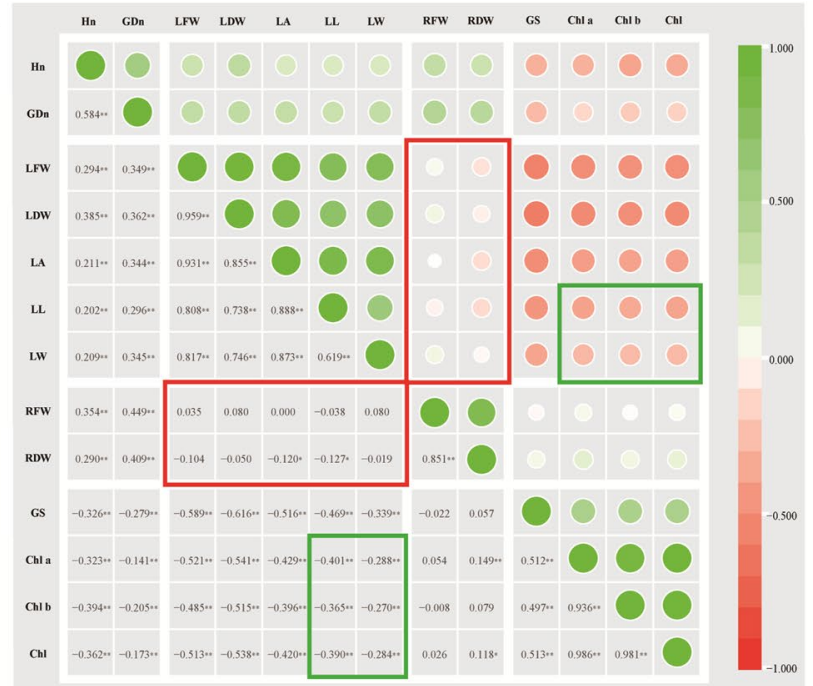

c

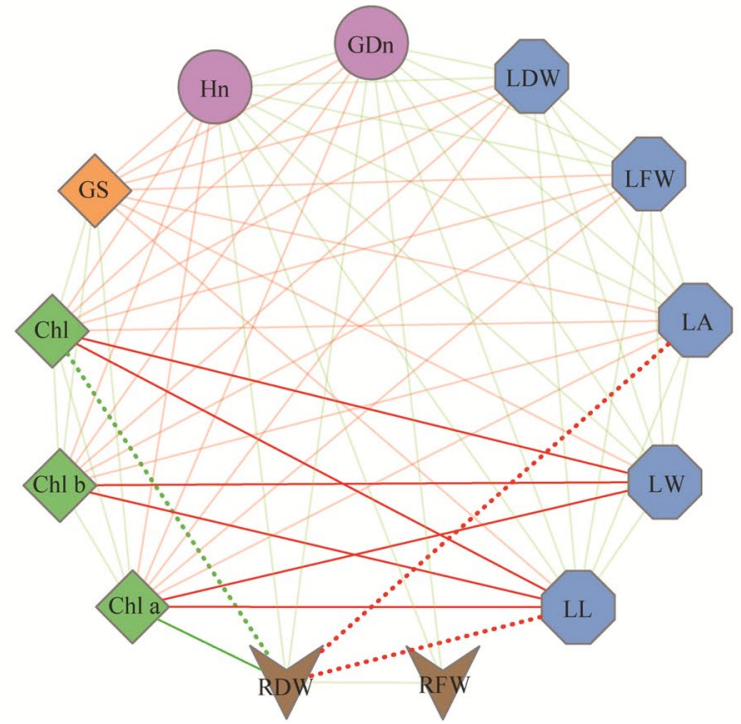

Fig. 3 Heat maps and network diagrams of correlation among characteristic parameters of Populus deltoides in a, c normal $\mathrm{N}$ supply $(\mathrm{CK})$ and $\mathbf{b}$, d low $\mathrm{N}$ supply (LN); *: $p<0.05$, **: $p<0.01$. In the network diagrams (c, d), red lines represent negative correlations, green lines positive correlation, solid lines $p<0.01$, dotted lines $p<0.05$; dark-colored lines indicate that the correlation was significantly different between the $\mathrm{CK}$ and $\mathrm{LN}$ treatments; light-colored

In the control treatment, the equation to calculate the comprehensive evaluation was:

$$
\begin{aligned}
P_{C E-i}= & {\left[0.4287 \times y\left(P C_{i 1}\right)\right]+\left[0.2304 \times y\left(P C_{i 2}\right)\right] } \\
& +\left[0.1873 \times y\left(P C_{i 3}\right)\right]+\left[0.1536 \times y\left(P C_{i 4}\right)\right]
\end{aligned}
$$

In the $\mathrm{LN}$ treatment, the equation used was:
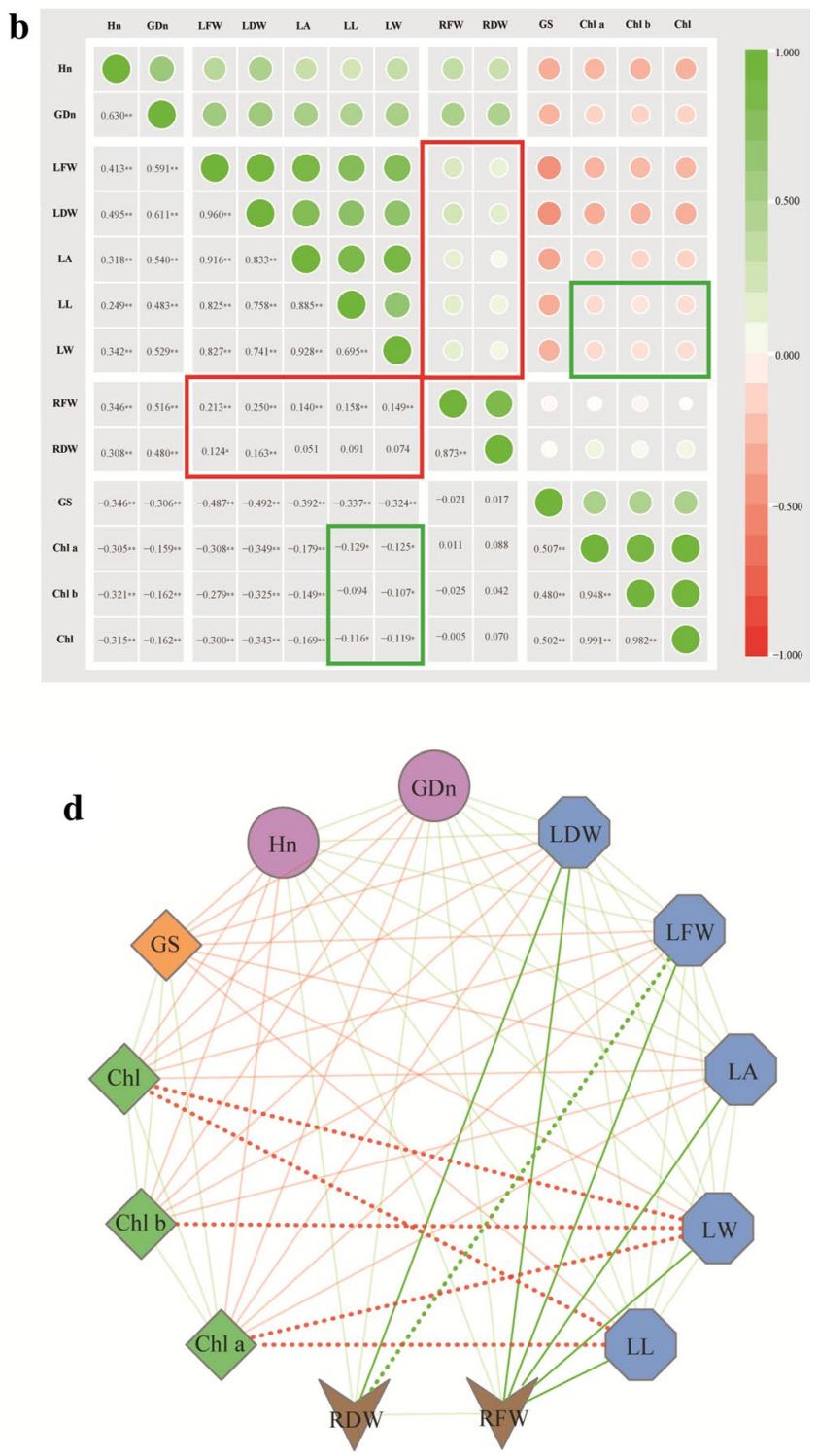

lines indicate that the correlation was not significantly different between CK and LN treatments. Hn, the height after treatment; GDn, the ground diameter after treatment; LFW, leaf fresh weight; LDW, leaf dry weight; LA, leaf area; LL, leaf length; LW, leaf width; RFW, root fresh weight; RDW, root dry weight; GS, glutamine synthetase activity; Chl a: chlorophyll-a content; $\mathrm{Chl}$ b: chlorophyll-b content; Chl: total chlorophyll content

$$
\begin{aligned}
P_{C E-i}= & {\left[0.4332 \times y\left(P C_{i 1}\right)\right]+\left[0.2297 \times y\left(P C_{i 2}\right)\right] } \\
& +\left[0.1993 \times y\left(P C_{i 3}\right)\right]+\left[0.1379 \times y\left(P C_{i 4}\right)\right]
\end{aligned}
$$

Based on their comprehensive evaluation results, the genotypes were divided into three categories: excellent growth category $\left(\mathrm{P}_{\mathrm{CE}}>\overline{\mathrm{x}}+\mathrm{SD}\right)$, medium growth category $\left(\bar{x}-\mathrm{SD}<\mathrm{P}_{\mathrm{CE}}<\bar{x} \mathrm{SD}\right)$ and poor growth category $\left(\mathrm{P}_{\mathrm{CE}}\right.$ $<\bar{x}-\mathrm{SD})$, where $\overline{\mathrm{x}}$ is the mean value of comprehensive 
Table 1 Eigenvalues and cumulative contribution rate of principal components extracted from growth indexes of Populus deltoides under normal N supply (CK) and low N supply (LN)

\begin{tabular}{|c|c|c|c|c|c|c|c|}
\hline \multirow[t]{2}{*}{ Treatments } & \multirow{2}{*}{$\begin{array}{l}\text { Principal } \\
\text { components }\end{array}$} & \multicolumn{3}{|c|}{ Extraction sums of squares } & \multicolumn{3}{|c|}{ Rotation sums of squares } \\
\hline & & Eigenvalue & $\begin{array}{l}\text { Variance contri- } \\
\text { bution rate }(\%)\end{array}$ & $\begin{array}{l}\text { Cumulative variance } \\
\text { contribution rate }(\%)\end{array}$ & Eigenvalue & $\begin{array}{l}\text { Variance contri- } \\
\text { bution rate }(\%)\end{array}$ & $\begin{array}{l}\text { Cumulative variance } \\
\text { contribution rate }(\%)\end{array}$ \\
\hline \multirow[t]{4}{*}{ CK } & 1 & 5.68 & 47.31 & 47.31 & 4.41 & 36.74 & 36.74 \\
\hline & 2 & 2.39 & 19.92 & 67.23 & 2.37 & 19.74 & 56.48 \\
\hline & 3 & 1.50 & 12.47 & 79.70 & 1.93 & 16.05 & 72.54 \\
\hline & 4 & 0.72 & 6.00 & 85.70 & 1.58 & 13.16 & 85.70 \\
\hline \multirow[t]{4}{*}{$\mathrm{LN}$} & 1 & 5.62 & 46.85 & 46.85 & 4.53 & 37.72 & 37.72 \\
\hline & 2 & 2.22 & 18.47 & 65.32 & 2.40 & 20.00 & 57.72 \\
\hline & 3 & 1.92 & 16.02 & 81.34 & 2.08 & 17.35 & 75.08 \\
\hline & 4 & 0.69 & 5.75 & 87.08 & 1.44 & 12.00 & 87.08 \\
\hline
\end{tabular}

Table 2 Rotated component matrix of the principle component analysis of Populus deltoides growth in conditions of normal N supply (CK) and low N supply (LN)

\begin{tabular}{|c|c|c|c|c|c|c|c|c|}
\hline \multirow[t]{3}{*}{ Parameters } & \multicolumn{4}{|c|}{ Normal N supply (CK) } & \multicolumn{4}{|c|}{ Low N supply (LN) } \\
\hline & \multicolumn{4}{|c|}{ Principal component } & \multicolumn{4}{|c|}{ Principal component } \\
\hline & 1 & 2 & 3 & 4 & 1 & 2 & 3 & 4 \\
\hline Leaf fresh weight (LFW) & 0.917 & -0.303 & -0.017 & 0.135 & 0.923 & -0.230 & 0.096 & 0.186 \\
\hline Leaf dry weight (LDW) & 0.844 & -0.359 & 0.018 & 0.205 & 0.842 & -0.279 & 0.133 & 0.271 \\
\hline Leaf area (LA) & 0.964 & -0.175 & -0.038 & 0.087 & 0.975 & -0.077 & 0.018 & 0.110 \\
\hline Leaf length (LL) & 0.847 & -0.180 & -0.083 & 0.094 & 0.906 & -0.045 & 0.076 & 0.016 \\
\hline Leaf width (LW) & 0.887 & -0.039 & 0.063 & 0.093 & 0.886 & -0.015 & 0.021 & 0.183 \\
\hline Chlorophyll-a content (Chl a) & -0.255 & 0.933 & 0.062 & -0.060 & -0.090 & 0.966 & 0.023 & -0.063 \\
\hline Chlorophyll-b content (Chl b) & -0.210 & 0.934 & 0.007 & -0.137 & -0.053 & 0.965 & -0.022 & -0.074 \\
\hline Glutamine synthetase activity (GS) & -0.460 & 0.498 & 0.063 & -0.271 & -0.349 & 0.579 & 0.093 & -0.296 \\
\hline Root fresh weight (RFW) & 0.022 & 0.004 & 0.941 & 0.202 & 0.106 & -0.002 & 0.949 & 0.137 \\
\hline Root dry weight (RDW) & -0.089 & 0.076 & 0.938 & 0.178 & 0.024 & 0.064 & 0.951 & 0.141 \\
\hline Height after treatment $(\mathrm{Hn})$ & 0.088 & -0.294 & 0.177 & 0.847 & 0.189 & -0.228 & 0.202 & 0.884 \\
\hline Ground diameter after treatment (GDn) & 0.291 & 0.008 & 0.329 & 0.780 & 0.478 & -0.064 & 0.441 & 0.608 \\
\hline
\end{tabular}

evaluation values and SD the standard deviation of comprehensive evaluation values.

Based on the classification results in the $\mathrm{CK}$ and $\mathrm{LN}$ treatments, the $P$. deltoides genotypes were divided into nine groups (Fig. 4a). Individuals in the excellent growth category $\left(\mathrm{P}_{\mathrm{CE}}>\bar{x} \mathrm{SD}\right)$ in both treatments showed high NUE, and were grouped into group $\mathrm{A}$, which included $26 \mathrm{P}$. deltoides genotypes (Fig. 4a and b). However, there were 24 individuals with low evaluation values $\left(\mathrm{P}_{\mathrm{CE}}<\bar{x} \mathrm{SD}\right)$ in both treatments, indicating that their NUE was low and named group C (Fig. 4a and b).

\section{Comparative analysis of plants with different nitrogen use efficiencies}

Based on the comprehensive evaluation, two groups with different NUEs were selected: group A (N-efficient genotypes) and $\mathrm{C}$ (N-inefficient genotypes). The scores of the four principal components of group A were higher than those of group $\mathrm{C}$, irrespective of the treatment (Fig. 5a and b). Moreover, compared with other principal components, the difference in leaf character (PC1) between the two groups was the largest. The PC1 score was the highest among the four principal components of group $\mathrm{A}$ in either treatment, whereas the opposite was true for group $\mathrm{C}$.

\section{Verification of analysis results}

The index parameters of six $P$. deltoides genotypes were measured under three N-level treatments (LN, CK and HN). These included H, GD, RFW, RDW, LFW, LDW, LA, 


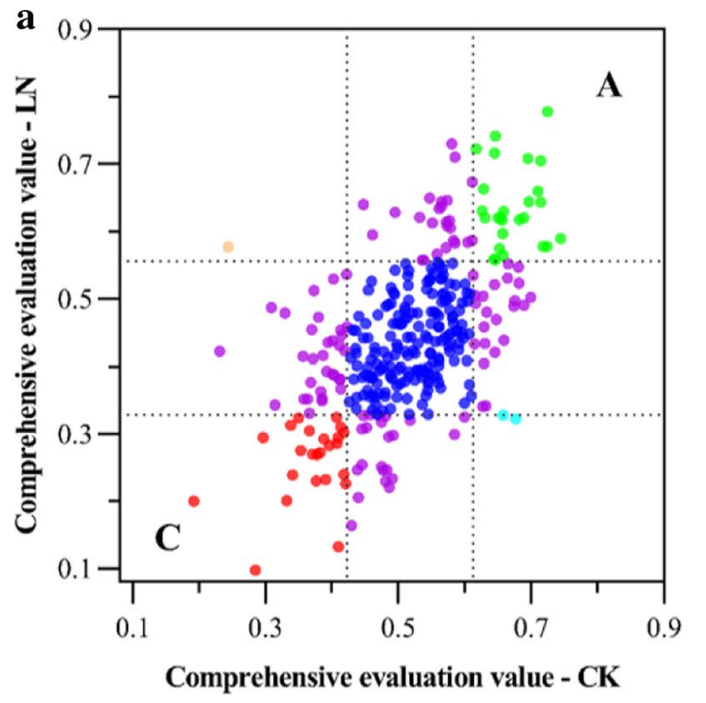

Fig. 4 Comprehensive evaluation, a classification and b statistics of Populus deltoides genotypes grown under normal $\mathrm{N}$ supply (CK) and low $\mathrm{N}$ supply (LN); $\mathrm{P}_{\mathrm{CE}-\mathrm{CK}}$, comprehensive evaluation value under $\mathrm{CK}$ treatment; $\mathrm{P}_{\mathrm{CE}-\mathrm{LN}}$, comprehensive evaluation value under LN treatment; $\bar{x}$, the mean value of comprehensive evaluation values; $\mathrm{SD}$, the standard deviation of comprehensive evaluation values. Green symbols, $\mathrm{P}_{\mathrm{CE}-\mathrm{CK}}>\bar{x}+\mathrm{SD}$ and $\mathrm{P}_{\mathrm{CE}-\mathrm{LN}}>\bar{x}+\mathrm{SD}$; blue symbols, $\bar{x}-\mathrm{SD}<\mathrm{P}_{\mathrm{CE}-\mathrm{CK}}<\bar{x}+\mathrm{SD}$ and $\bar{x}-\mathrm{SD}<\mathrm{P}_{\mathrm{CE}-\mathrm{LN}}<\bar{x}+\mathrm{SD}$;

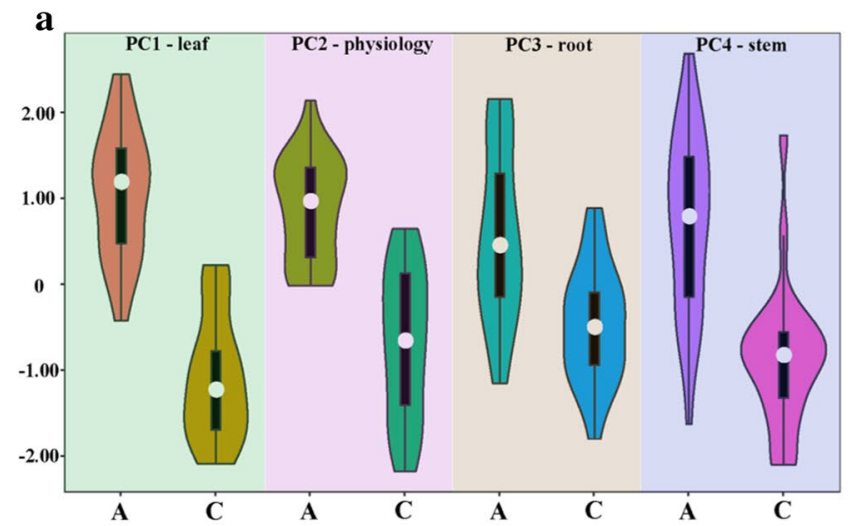

Fig. 5 Score of principal components of N-efficient (group A) and $\mathrm{N}$-inefficient (group C) Populus deltoides genotypes under a normal $\mathrm{N}$ supply and b low N supply; PC1-leaf, PC2-physiology, PC3-root

LL, LW, Chl a, Chl b, Pn, Tr, SFW (stem fresh weight), SDW (stem dry weight), PFW (petiole fresh weight) and PDW (petiole dry weight). The same comprehensive evaluation analysis was used to evaluate the plants, and the results show that in LN, control, HN treatments, the comprehensive evaluation values of the three genotypes selected from group A were higher than those of the three from group C (Fig. 6). red symbols, $\mathrm{P}_{\mathrm{CE}-\mathrm{CK}}<\bar{x}-\mathrm{SD}$ and $\mathrm{P}_{\mathrm{CE}-\mathrm{LN}}<\bar{x}-\mathrm{SD}$; orange symbols, $\mathrm{P}_{\mathrm{CE}-\mathrm{CK}}<\bar{x}-\mathrm{SD}$ and $\mathrm{P}_{\mathrm{CE}-\mathrm{LN}}>\bar{x}+\mathrm{SD}$; light blue symbols, $\mathrm{P}_{\mathrm{CE}-\mathrm{CK}}>\bar{x}+\mathrm{SD}$ and $\mathrm{P}_{\mathrm{CE}-\mathrm{LN}}<\bar{x}-\mathrm{SD}$; purple symbols, $\mathrm{P}_{\mathrm{CE}-\mathrm{CK}}<\bar{x}-$ $\mathrm{SD}$ and $\bar{x}-\mathrm{SD}<\mathrm{P}_{\mathrm{CE}-\mathrm{LN}}<\bar{x}+\mathrm{SD}, \quad \mathrm{P}_{\mathrm{CE}-\mathrm{CK}}>\bar{x}+\mathrm{SD}$ and $\bar{x}-$ $\mathrm{SD}<\mathrm{P}_{\mathrm{CE}-\mathrm{LN}}<\bar{x}+\mathrm{SD}, \bar{x}-\mathrm{SD}<\mathrm{P}_{\mathrm{CE}-\mathrm{CK}}<\bar{x}+\mathrm{SD}$ and $\mathrm{P}_{\mathrm{CE}-\mathrm{LN}}<\bar{x}-\mathrm{SD}$, $\bar{x}-\mathrm{SD}<\mathrm{P}_{\mathrm{CE}-\mathrm{CK}}<\bar{x}+\mathrm{SD}$ and $\mathrm{P}_{\mathrm{CE}-\mathrm{LN}}>\bar{x}+\mathrm{SD}$. A, N-efficient genotypes; $\mathrm{C}, \mathrm{N}$-inefficient genotypes

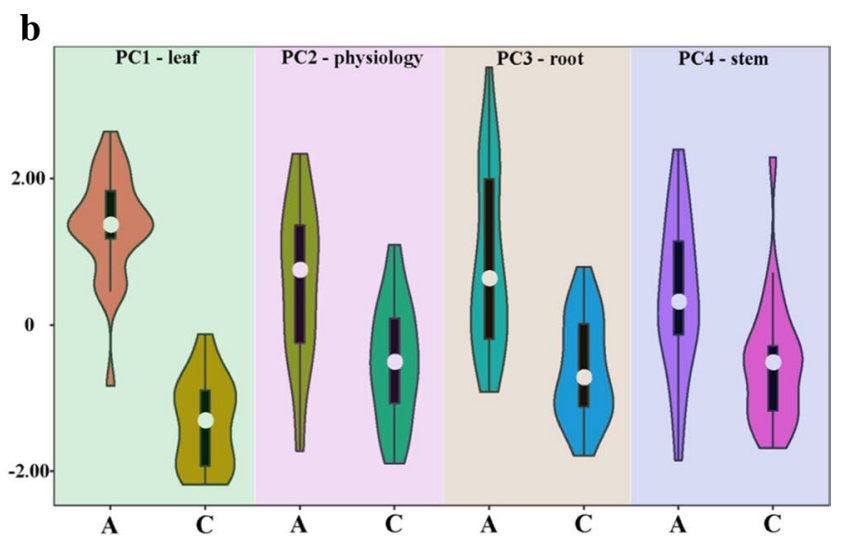

and PC4-stem represent the principal components of leaf character, physiological index, root character and stem character, respectively

\section{Discussion}

\section{Effects of low $\mathbf{N}$ stress on plant growth}

Since $\mathrm{N}$ is an essential element for plant growth and development; growth will be significantly inhibited under conditions of low N availability (Kavoosi et al. 2014; Xu et al. 2017; Li et al. 2018). Lu et al. (2019) studied the wood properties of Populus during acclimation to low $\mathrm{N}\left(50 \mu \mathrm{M} \mathrm{NH} \mathrm{N}_{4} \mathrm{NO}_{3}\right)$. They found that the width and number of cell layers in the 
Fig. 6 Comprehensive evaluation value of Populus deltoides genotypes under low nitrogen $\left(\mathrm{LN}_{2}\right)$, normal nitrogen levels $\left(\mathrm{CK}_{2}\right)$ and high nitrogen $\left(\mathrm{HN}_{2}\right)$ in the verification test. A-1, A-2 and A-3 represent the three $\mathrm{N}$-efficient genotypes; C-1, C-2 and $\mathrm{C}-3$ the three $\mathrm{N}$-inefficient genotypes

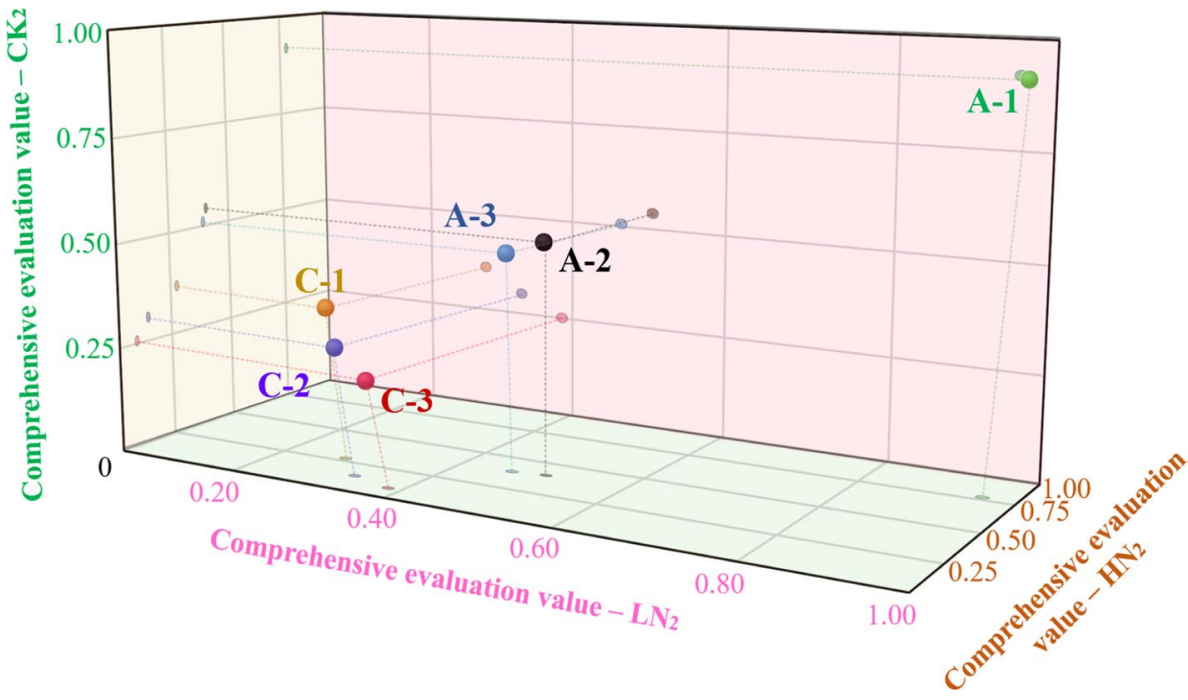

xylem decreased, and wood fiber content was reduced. It has also been shown that $\mathrm{N}$ deficiency affected the accumulation of $\mathrm{N}$, phosphorus and potassium in roots, leaves and stems of Pistacia chinensis Bunge seedlings. More nutrients were transported to the root system to promote the growth of fine roots to reduce the negative effects of $\mathrm{N}$ deficiency (Song et al. 2019). In addition, when subjected to $\mathrm{N}$ deficiency $\left(0.25 \mathrm{mM} \mathrm{NH}_{4} \mathrm{NO}_{3}\right)$, root biomass of Populus cathayana Rehd. increased and stem and leaf biomass decreased. This suggests that, with the change of $\mathrm{N}$ levels in the environment, the internal resource allocation by the plant changed adaptively (Luo et al. 2019). In addition, chlorophyll concentrations, leaf area, net photosynthetic rates and enzyme activities have been shown to be less under low $\mathrm{N}$ conditions, which eventually leads to reductions in biomass ( $\mathrm{Li}$ et al. 2012; Luo et al. 2015, 2019; Lu et al. 2019; Su et al. 2019).

In this study, the growth of 338 P. deltoides genotypes was evaluated under a normal $\mathrm{N}$ supply and low $\mathrm{N}$ stress. Compared with the CK treatment, chlorophyll levels of the leaves and the growth of roots, stem, and leaf tissues were significantly lower in LN treatment $(p<0.01$; Fig. 2$)$. As $\mathrm{N}$ levels decreased, the correlation between the trait indicators changed. The negative correlation between the leaf morphological parameters (area, width, length) and chlorophyll content was weaker in the LN treatment (Fig. 3). This indicated that the extent of the inhibition caused by $\mathrm{N}$ deficiency differed for leaf development and for chlorophyll synthesis. Furthermore, the positive correlation between the root growth parameters (root fresh weight, RFW and root dry weight, RDW) and the leaf parameters (leaf fresh weight, LFW, leaf dry weight, LDW, area, width and length) was stronger under LN conditions (Fig. 3). This indicates that under $\mathrm{N}$ stress, leaf development was more dependent on the status of the root system to obtain mineral elements and other substances. Simultaneously, the development of the root system required more nutrients provided by photosynthesis.

Contrary to previous studies, low $\mathrm{N}$ stress did not promote root growth in this study but significantly inhibited root growth. Comparing the results of different studies, it was found that the growth and development of roots under low $\mathrm{N}$ stress was related to treatment time. When the treatment time is relatively short (3-7 weeks), the length, surface area and biomass of the roots, especially of fine roots, are significantly stimulated by $\mathrm{N}$ starvation (Li et al. 2012; Luo et al. 2015, 2019; Meng et al. 2018). However, with an increase of stress time (5-6 months), root growth is significantly inhibited, although root to shoot ratios increases (Song et al. 2019). The root system absorbs the necessary nutrients (mineral elements, organic matter and water) for plant growth and transports them to the leaves through the xylem. In the leaves, nutrients are transformed into sugars, proteins and other compounds via metabolic processes such as photosynthesis and transpiration. These compounds are then transported to various organs (roots, stems and leaves) to promote growth and development (Nunes-Nesi et al. 2010; $\mathrm{Xu}$ et al. 2012). When under low $\mathrm{N}$ stress, roots react to the deficiency, leading to increased transport to the roots of compounds synthesized in the leaves. This promoted the growth of fine roots and thus the absorption of more nutrients to be transported to the leaves. With the prolongation of stress time, compounds produced by leaves could no longer meet the requirements for root growth and growth of the root system would eventually be inhibited.

\section{Evaluation of plant nitrogen use efficiency}

Different genotypes of the same species show contrasting adaptabilities to growing conditions, and different tolerances 
to biotic and abiotic stresses (Guo and Zhang 2010; Liu et al. 2015; Zhao et al. 2016a, b; Ferreira et al. 2018; Ghezehei et al. 2019; Zhang et al. 2020). Kalcsits and Guy (2016) studied the variability of nitrogen uptake, assimilation and allocation traits of 25 Populus balsamifera L. genotypes from five climatically different provenances. There was extensive genotypic variation in $\mathrm{N}$ isotope composition, and a high degree of genotypic variation in $\mathrm{N}$ use traits was identified at both the provenance and genotypic level. In this study, the growth performance of a natural P. deltoides population (338 genotypes) under low and normal $\mathrm{N}$ conditions was evaluated using PCA combined with a fuzzy mathematics membership function. According to the evaluation results, all the genotypes could be divided into nine categories (Fig. 5), indicating a wide genotypic diversity in NUE and $\mathrm{N}$ tolerance. Due to the existence of this genotypic diversity, different genotypes could be selected specifically to study the differences in $\mathrm{N}$ absorption, transportation, assimilation and utilization to explain the phenotypic and physiological differences.

At the same time, among the evaluation models established for the two $\mathrm{N}$ treatments in this study, the response by leaf traits accounted for the largest proportion of the variability. This was followed by chlorophyll content and the activity of key enzymes such as glutamine synthetase. The contribution of stem growth, which was lower than root growth, was the smallest. These results suggest that changes in leaf characteristics of size, color and biomass could be used as a key factor to evaluate plant nitrogen use efficiencies of plants. Previous studies have also found that leafrelated traits (morphological, physiological and nutritional status) were sensitive to changes in the growth environment (Marron et al. 2005; Pérezharguindeguy et al. 2013; Tsujii et al. 2017; Mao et al. 2018; Wang et al. 2018a, b; Jiang et al. 2019).

\section{Morphological and physiological differences among genotypes with different nitrogen use efficiencies}

In previous studies, genotypes with different NUE were used to analyzed characteristics of $\mathrm{N}$ utilization and the phenotypic and physiological adaptability of plants to low $\mathrm{N}$ stress (Shen et al. 2013; Quan et al. 2016; Wang et al. 2016; Zhu et al. 2017). Plant growth was inhibited under low $\mathrm{N}$ conditions, and compared with plants with low NUE, aboveground biomass, leaf area and enzyme activities related to $\mathrm{N}$ absorption, transportation and assimilation were higher in plants with high NUE. Furthermore, nutritional status (carbon and N) were better than plants with low NUE (Li et al. 2012; Luo et al. 2013; Meng et al. 2018). In this study, the growth of two groups of plants with different NUE were analyzed under different $\mathrm{N}$ levels. Growth of $\mathrm{N}$-efficient plants (especially the leaves) was better than that of $\mathrm{N}$-inefficient plants (Fig. 6). Maintaining high growth and physiological activities under stress indicates a strong adaptability to adversity (Zhao et al. 2016a, b; Liu et al. 2020). In addition, a verification experiment was carried out for genotypes with different NUE, and measurement indexes (photosynthesis, transpiration, stem biomass and petiole biomass) and an excess $\mathrm{N}$ treatment were added. The results show that the previous evaluation results were reliable.

It has been shown that gene expression of plants changes during $\mathrm{N}$ starvation. There are some differences in gene expression between $\mathrm{N}$-efficient and $\mathrm{N}$-inefficient genotypes (Wang et al. 2016; Li et al. 2020). In the present study, the nitrogen use efficiency of $338 P$. deltoides genotypes had been preliminarily evaluated, and the adaptability to $\mathrm{N}$ stress had also been analyzed. As a result, genotypes with different NUE were selected to study the molecular mechanism of different $\mathrm{N}$ use strategies, which is of great significance for breeding poplar varieties for high NUE.

\section{Conclusions}

The growth (roots, stems and leaves) and chlorophyll synthesis of 338 P. deltoides genotypes were significantly inhibited under $\mathrm{N}$ starvation. The correlation between the traits, especially between root and leaf traits, changed under low $\mathrm{N}$ conditions. This indicated that nutrient transport and distribution changed to adapt and to reduce the negative effects of a low $\mathrm{N}$ environment. In addition, based on the evaluation results obtained under low and normal $\mathrm{N}$ conditions, the genotypes were divided into nine categories. This indicated a wide genotypic diversity in NUE and $\mathrm{N}$ tolerance of the population. Under conditions of starvation or normal $\mathrm{N}$ levels, the growth of $\mathrm{N}$-efficient genotypes (especially the growth of leaves) was better than the growth of $\mathrm{N}$-inefficent genotypes. Growth status of the leaves (area, biomass and chlorophyll content) was a good indicator of NUE and could be used as the basis for selecting genotypes. Moreover, N utilization characteristics of the plants were stable and the evaluation results reliable. Therefore, based on the results of this study, plants with different NUE should be screened for further study to clarify the different $\mathrm{N}$ metabolism strategies in $P$. deltoides. This could provide a basis for screening and cultivating plants with high NUE.

Acknowledgements The authors would like to thank financial support this research and the State Key Laboratory of Tree Genetics and Breeding, Research Institute of Forestry, Chinese Academy of Forestry for the instrument support.

Open Access This article is licensed under a Creative Commons Attribution 4.0 International License, which permits use, sharing, adaptation, distribution and reproduction in any medium or format, as long as you give appropriate credit to the original author(s) and the 
source, provide a link to the Creative Commons licence, and indicate if changes were made. The images or other third party material in this article are included in the article's Creative Commons licence, unless indicated otherwise in a credit line to the material. If material is not included in the article's Creative Commons licence and your intended use is not permitted by statutory regulation or exceeds the permitted use, you will need to obtain permission directly from the copyright holder. To view a copy of this licence, visit http://creativecommons. org/licenses/by/4.0/.

\section{References}

Balasus A, Bischoff WA, Schwarz A, Scholz V, Kern J (2012) Nitrogen fluxes during the initial stage of willows and poplars in shortrotation coppices. J Plant Nutr Soil Sci 175(5):729-738

Bian HY, Geng QH, Xiao HR, Shen CQ, Li Q, Cheng XL, Luo YQ, Ruan HH, Xu X (2019) Fine root biomass mediates soil fauna community in response to nitrogen addition in poplar plantations (Populus deltoides) on the east coast of China. Forests 10(2):122

Binkley D, Högberg P (2016) Tamm Review: Revisiting the influence of nitrogen deposition on Swedish forests. For Ecol Manag 368:222-239

Cánovas FM, Cañas RA, de la Torre FN, Pascual MB, Castro-Rodríguez V, Avila C (2018) Nitrogen metabolism and biomass production in forest trees. Front Plant Sci 9:1449

Chen C, Chu YG, Ding CJ, Su XH, Huang QJ (2020) Genetic diversity and population structure of black cottonwood (Populus deltoides) revealed using simple sequence repeat markers. BMC Genet 21(1):2

Dathe A, Postma JA, Postma-Blaauw MB, Lynch JP (2016) Impact of axial root growth angles on nitrogen acquisition in maize depends on environmental conditions. Ann Bot 118(3):401-414

Dong TF, Duan BL, Zhang S, Korpelainen H, Niinemets U, Li CY (2016) Growth biomass allocation and photosynthetic responses are related to intensity of root severance and soil moisture conditions in the plantation tree Cunninghamia lanceolata. Tree Physiol 36(7):807-817

Fahrenkrog AM, Neves LG, Resende MF, Dervinis C, Davenport R, Barbazuk WB, Kirst M (2017) Population genomics of the eastern cottonwood (Populus deltoides). Ecol Evol 7(22):9426-9440

Ferreira GWD, Oliveira FCC, Silva LOG, Souza JJLL, Soares EMB, Araújo EF, Silva IR (2018) Nitrogen alters initial growth fine-root biomass and soil organic matter properties of a Eucalyptus dunnii Maiden plantation in a recently afforested grassland in southern Brazil. Forests 9(2):62

Gao K, Chen FJ, Yuan LX, Zhang FS, Mi GH (2015) A comprehensive analysis of root morphological changes and nitrogen allocation in maize in response to low nitrogen stress. Plant Cell Environ 38(4):740-750

Ghezehei SB, Nichols EG, Hazel DW (2016) Early clonal survival and growth of poplars grown on North Carolina Piedmont and Mountain marginal lands. BioEnergy Res 9(2):548-558

Ghezehei SB, Nichols EG, Maier CA, Hazel DW (2019) Adaptability of Populus to physiography and growing conditions in the southeastern USA. Forests 10(2):118

Guo XY, Zhang XS (2010) Performance of 14 hybrid poplar clones grown in Beijing China. Biomass Bioenergy 34(6):906-911

Hodge A, Robinson D, Fitter A (2000) Are microorganisms more effective than plants at competing for nitrogen? Trends Plant Sci 5(7):304-308

Jansson S, Douglas CJ (2007) Populus: A model system for plant biology. Annu Rev Plant Biol 58(1):435-458

Jiang DL, Geng QH, Li Q, Luo YQ, Vogel J, Shi Z, Ruan H, Xu X (2019) Nitrogen and phosphorus resorption in planted forests worldwide. Forests 10(3):201
Kalcsits LA, Guy RD (2016) Genotypic variation in nitrogen isotope discrimination in Populus balsamifera L. clones grown with either nitrate or ammonium. J Plant Physiol 201:54-61

Kavoosi G, Balotf S, Eshghi H, Hasani H (2014) Analysis of nitrate reductase mRNA expression and nitrate reductase activity in response to nitrogen supply. Mol Biol Res Commun 3(2):75-84

Kiba T, Krapp A (2016) Plant nitrogen acquisition under low availability: regulation of uptake and root architecture. Plant Cell Physiol 57(4):707-714

Li H, Li MC, Luo J, Cao X, Qu L, Gai Y, Jiang XN, Liu TX, Bai H, Janz D, Polle A, Peng CH, Luo ZB (2012) N-fertilization has different effects on the growth, carbon and nitrogen physiology, and wood properties of slow- and fast-growing Populus species. J Exp Bot 63(17):6173-6185

Li MX, Xu JS, Wang XX, Fu H, Zhao ML, Wang H, Shi L (2018) Photosynthetic characteristics and metabolic analyses of two soybean genotypes revealed adaptive strategies to low-nitrogen stress. J Plant Physiol 229:132-141

Li Q, Ding GD, Yang NM, White PJ, Ye XS, Cai HM, Lu JW, Shi L, $\mathrm{Xu}$ FS (2020) Comparative genome and transcriptome analysis unravels key factors of nitrogen use efficiency in Brassica napus L. Plant Cell Environ 43(3):712-731

Lichtenthaler HK, Wellburn AR (1983) Determinations of total carotenoids and chlorophylls a and $\mathrm{b}$ of leaf extracts in different solvents. Biochem Soc Trans 11(5):591-592

Liu MR, Yin SP, Si DJ, Shao LT, Li Y, Zheng M, Wang FW, Li SC, Liu GF, Zhao XY (2015) Variation and genetic stability analyses of transgenic TaLEA poplar clones from four different sites in China. Euphtyica 206:331-342

Liu XJ, An BY, Gu N, Guo CN, Sun XG, Wang H (2020) Response of leaf photosynthetic characteristics of Syringa oblata and Syringa reticulata var. mandshurica to chilling stress. J For Res 31:521-530

Lu Y, Deng SR, Li ZR, Wu JT, Liu QF, Liu WZ, Yu WJ, Zhang YH, Shi WG, Zhou J, Li H, Polle A, Luo ZB (2019) Competing endogenous RNA networks underlying anatomical and physiological characteristics of poplar wood in acclimation to low nitrogen availability. Plant Cell Physiol 60(11):2478-2495

Luo J, Li H, Liu TX, Polle A, Peng CH, Luo ZB (2013) Nitrogen metabolism of two contrasting poplar species during acclimation to limiting nitrogen availability. J Exp Bot 64(14):4207-4224

Luo J, Zhou J, Li H, Shi WG, Polle A, Lu MZ, Sun XM, Luo ZB (2015) Global poplar root and leaf transcriptomes reveal links between growth and stress responses under nitrogen starvation and excess. Tree Physiol 35(12):1283-1302

Luo J, Zhou JJ, Masclaux-Daubresse C, Wang N, Wang H, Zheng B (2019) Morphological and physiological responses to contrasting nitrogen regimes in Populus cathayana is linked to resources allocation and carbon/nitrogen partition. Environ Exp Bot 162:247-255

Luo ZB, Luo J (2017) Uncovering the physiological mechanisms that allow nitrogen availability to affect drought acclimation in Catalpa bungei. Tree Physiol 37(11):1453-1456

Mamashita T, Larocque GR, DesRochers A, Beaulieu J, Thomas BR, Mosseler A, Major J, Sidders D (2015) Short-term growth and morphological responses to nitrogen availability and plant density in hybrid poplars and willows. Biomass Bioenergy 81:88-97

Mao QG, Lu XK, Mo H, Gundersen P, Mo JM (2018) Effects of simulated $\mathrm{N}$ deposition on foliar nutrient status $\mathrm{N}$ metabolism and photosynthetic capacity of three dominant understory plant species in a mature tropical forest. Sci Total Environ 610:555-562

Marron N, Villar M, Dreyer E, Delay D, Boudouresque E, Petit J, Delmotte F, Guehl J, Brignolas F (2005) Diversity of leaf traits related to productivity in 31 Populus deltoides $\times$ Populus nigra clones. Tree Physiol 25(4):425-435 
Meng S, Wang S, Quan J, Su WL, Lian CL, Wang DL, Xia X, Yin WL (2018) Distinct carbon and nitrogen metabolism of two contrasting poplar species in response to different $\mathrm{N}$ supply levels. Int $\mathrm{J}$ Mol Sci 19(8):2302

Nunes-Nesi A, Fernie AR, Stitt M (2010) Metabolic and signaling aspects underpinning the regulation of plant carbon nitrogen interactions. Mol Plant 3(6):973-996

Ouyang L, Pei HY, Xu ZH (2017) Low nitrogen stress stimulating the indole-3-acetic acid biosynthesis of Serratia sp ZM is vital for the survival of the bacterium and its plant growth-promoting characteristics. Arch Microbiol 199(3):425-432

Pérezharguindeguy N, Díaz S, Garnier E, Lavorel S, Poorter H, Jaureguiberry P, Bretharte MS, CornwellWK CJM, Gurvich DE (2013) New handbook for standardized measurement of plant functional traits worldwide. Aust J Bot 61(3):167-234

Polle A, Janz D, Teichmann T, Lipka V (2013) Poplar genetic engineering: promoting desirable wood characteristics and pest resistance. Appl Microbiol Biotechnol 97(13):5669-5679

Qin L, Walk T, Han PP, Chen LY, Zhang S, Li YS, Hu XJ, Xie LH, Yang Y, Liu JP, Lu X, Yu CB, Tian J, Shaff JE, Kochian LV, Liao X, Liao H (2019) Adaption of roots to nitrogen deficiency revealed by $3 \mathrm{D}$ quantification and proteomic analysis. Plant Physiol 179(1):329-347

Quan XY, Qian QF, Ye ZL, Zeng JB, Han ZG, Zhang GP (2016) Metabolic analysis of two contrasting wild barley genotypes grown hydroponically reveals adaptive strategies in response to low nitrogen stress. J Plant Physiol 206:59-67

Ren YY, Sun FS, Hou J, Chen L, Zhang YY, Kang XY, Wang YW (2015) Differential profiling analysis of miRNAs reveals a regulatory role in low N stress response of Populus. Funct Integr Genomics 15(1):93-105

Rennenberg H, Wildhagen H, Ehlting B (2010) Nitrogen nutrition of poplar trees. Plant Biol 12(2):275-291

Robertson GP, Vitousek PM (2009) Nitrogen in agriculture: balancing the cost of an essential resource. Annu Rev Environ Resour 34(1):97-125

Rubio-Asensio JS, Bloom AJ (2017) Inorganic nitrogen form: a major player in wheat and Arabidopsis responses to elevated $\mathrm{CO}_{2}$. J Exp Bot 68(10):2611-2625

Shen JB, Li CJ, Mi GH, Li L, Yuan LX, Jiang RF, Zhang FS (2013) Maximizing root/rhizosphere efficiency to improve crop productivity and nutrient use efficiency in intensive agriculture of China. J Exp Bot 64(5):1181-1192

Song XH, Wan FF, Chang XC, Zhang J, Sun MH, Liu Y (2019) Effects of nutrient deficiency on root morphology and nutrient allocation in Pistacia chinensis Bunge seedlings. Forests 10(11):1035

Su T, Han M, Min J, Cao D, Zhai GQ, Zhou HY, Li NY, Li MZ (2019) Genome-wide characterization of AspATs in Populus: gene expression variation and enzyme activities in response to nitrogen perturbation. Forests 10(5):449

Sun F, Tariq A, Chen H, He QJ, Guan YX, Pan K, Chen SY, Li JT, Zhao CC, Wang H, Gu YF (2017) Effect of nitrogen and phosphorus application on agricultural soil food webs. Arch Agron Soil Sci 63(8):1176-1186
Sutton MA, Oenema O, Erisman JW, Leip A, van Grinsven H, Winiwarter W (2011) Too much of a good thing. Nature 472(7342):159-161

Tavarini S, Pagano I, Guidi L, Angelini LG (2016) Impact of nitrogen supply on growth steviol glycosides and photosynthesis in Stevia rebaudiana Bertoni. Plant Biosyst Int J Deal Asp Plant Biol 150(5):953-962

Tegeder M, Masclaux-Daubresse C (2018) Source and sink mechanisms of nitrogen transport and use. New Phytol 217(1):35-53

Truax B, Gagnon D, Fortie J, Lambert F (2014) Biomass and volume yield in mature hybrid poplar plantations on temperate abandoned farmland. Forests 5(12):3107-3130

Tsujii Y, Onoda Y, Kitayama K (2017) Phosphorus and nitrogen resorption from different chemical fractions in senescing leaves of tropical tree species on Mount Kinabalu. Borneo Oecologia 185(2):171-180

Wang F, Zhang QH, Tian YG, Yang SC, Wang HW, Wang LK, Li YL, Zhang P, Zhao XY (2018a) Comprehensive assessment of growth traits and wood properties in half-sib Pinus koraiensis families. Euphytica 214(11):1-15

Wang M, Zhang W, Li N, Liu Y, Zheng X, Hao G (2018) Photosynthesis and growth responses of Fraxinus mandshurica Rupr. seedlings to a gradient of simulated nitrogen deposition. Ann For Sci 75(1):1

Wang XL, Li XD, Zhang S, Korpelainen H, Li CY (2016) Physiological and transcriptional responses of two contrasting Populus clones to nitrogen stress. Tree Physiol 36(5):628-642

$\mathrm{Xu}$ GH, Fan XR, Miller AJ (2012) Plant nitrogen assimilation and use efficiency. Annu Rev Plant Biol 63(1):153-182

Xu W, Liu S, You X, Mei YY, Wang D, Wang NN (2017) Overexpression of GmATG8c gene enhances tolerance to low nitrogen and increases yield in soybean. J Plant Physiol 53(002):241-247

Zeng J, Sheng HJ, Liu Y, Wang Y, Wang Y, Kang HY, Fan X, Sha LN, Yuan S, Zhou YH (2017) High nitrogen supply induces physiological responsiveness to long photoperiod in barley. Front Plant Sci 8:569

Zhang YT, Zhu QY, Zhang M, Guo ZH, Yang JJ, Mo JX, Cui JB, Hu HL, Xu J (2020) Individual Cryptomeria fortunei Hooibrenk clones show varying degrees of chilling stress resistance. Forests 11(2): 189

Zhao XY, Xia H, Wang XW, Wang C, Liang DY, Li KL, Liu GF (2016) Variance and stability analyses of growth characters in half-sib Betula platyphylla families at three different sites in China. Euphytica 208:173-186

Zhao XY, Zheng TC, Shao LT, Xiao ZH, Wang FW, Li SC, Zang LN, Zheng M, Li Y, Qu GZ (2016) Variation analysis of physiological traits in Betula platyphylla overexpressing TaLEA-ThbZIP gene under salt stress. PLOS ONE 11(11):e0164820

Zhu JL, Bo HJ, Li X, Song LJ, Wang J, Nie LS, Tian J (2017) Effects of soil water and nitrogen on the stand volume of four hybrid Populus tomentosa clones. Forests 8(7):250

Publisher's Note Springer Nature remains neutral with regard to jurisdictional claims in published maps and institutional affiliations. 